\title{
Dansyl-Based Fluorescent Films Prepared by Chemical and Electrochemical Methods: Cyclic Voltammetry, AFM and Spectrofluorimetry Characterization
}

\author{
Ana Julia C. Silva, ${ }^{a}$ José Ginaldo Silva Jr., ${ }^{b}$ Severino Alves Jr., ${ }^{c}$ Josealdo Tonholo ${ }^{a}$ and \\ Adriana S. Ribeiro $*$,a \\ ${ }^{a}$ Instituto de Química e Biotecnologia, Universidade Federal de Alagoas, \\ Campus A. C. Simões, Tabuleiro do Martins, 57072-970 Maceió-AL, Brazil \\ ${ }^{b}$ Instituto Federal de Alagoas, Rua Lourival Alfredo 176, Poeira, \\ 57160-000 Marechal Deodoro-AL, Brazil \\ 'Departamento de Química Fundamental, Universidade Federal de Pernambuco, \\ 50670-901 Recife-PE, Brazil
}

\begin{abstract}
Filmes fluorescentes baseados em derivados de dansila foram preparados a partir de duas metodologias diferentes. Em uma delas, a superfície de um eletrodo de óxido de índio dopado com estanho (ITO) foi coberta com um filme de quitosana e o polímero foi posteriormente derivatizado com cloreto de dansila, enquanto que na outra metodologia, um filme de dansilglicina foi depositado eletroquimicamente sobre ITO. A técnica de microscopia de força atômica (AFM) foi usada para mapear a superfície dos filmes. A comparação das propriedades eletroquímicas, fotoquímicas e morfológicas destes filmes indicou que o filme de dansilglicina depositado eletroquimicamente sobre ITO apresentou resposta eletroquímica, nível de fluorescência mais intenso, maior rugosidade superficial e maior área superficial relativa em comparação com o seu homólogo quitosana-cloreto de dansila. Esse comportamento pode ser atribuído ao maior número de sítios ativos presentes na estrutura bem organizada do filme eletrodepositado em comparação com os filmes produzidos quimicamente.
\end{abstract}

Dansyl-based fluorescent films were prepared by two different methods. In one of them, the surface of an indium tin oxide (ITO) electrode was coated with a film of chitosan and the polymer subsequently derivatized with dansyl chloride, whilst in the second method a film of dansylglycine was electrochemically deposited on the ITO surface. Atomic force microscopy (AFM) was employed to map the surfaces of the films. Comparison of the morphological, photochemical and electrochemical properties of these films indicated that the dansylglycine film electrodeposited on ITO exhibited electrochemical response, emitted a higher level of fluorescence, presented greater surface roughness and larger relative surface area in comparison with its dansyl chloridechitosan counterpart. This behavior can be attributed to the higher number of active sites present in the well-organized and rough structure of the electrodeposited film in comparison with the chemically produced films.

Keywords: fluorescent films, chitosan, dansyl derivatives, atomic force microscopy

\section{Introduction}

Surface immobilization of organic molecules on various solid supports to prepare thin films with desired properties has gained considerable research interest in the past few decades. ${ }^{1}$ This is because, on one hand, it can offer model systems to study surface-dependent phenomena

*e-mail: aribeiro@qui.ufal.br like catalysis, ${ }^{2}$ adhesion, ${ }^{3}$ or wetting, ${ }^{4}$ and, on the other hand, it plays a great role in the design and preparation of functionalized surface materials. ${ }^{5,6}$ The photochemical, photophysical and electrochemical properties of these functional films offer a wide range of potential applications in nonlinear optics, ${ }^{7}$ displays, ${ }^{8,9}$ biomedicine and chemical sensors. ${ }^{10}$

Fluorescent films are of particular interest by virtue of their specific advantages regarding sensitivity and 
selectivity, once such films are reusable and are readily fabricated into devices. ${ }^{6}$ Some special fluorophores, which may have two parts in their structures, namely, the donor part and the acceptor part connected by a single bond, can present twisted intra-molecular charge transfer (TICT) phenomenon. ${ }^{11}$ When excited, the donor part of the fluorophore may rotate around the single bond and transfer an electron to the acceptor part. As a result, the molecular structure of the fluorophore changes from a planar conformation to a perpendicular conformation, exhibiting two excited states, one is the TICT state and the other is the non-charge transfer state (non-CT state). TICT phenomenon has been reported for fluorophores immobilized on a substrate surface by Ding et al., ${ }^{1}$ giving a new approach for designing novel functional films.

TICT phenomenon can occur in the derivatives of 1-(dimethylamino)-naphthalene-5-sulfonyl), usually called dansyl (Figure 1), in which dimethylamino moiety functions as a donor part and naphthalene sulfonyl as an acceptor part. The dansyl fluorophore exhibits intense absorption bands in the near UV and a strong fluorescence in the visible region with high emission quantum yields. ${ }^{12}$ These characteristics, together with the synthetic flexibility of the sulfonyl group, have led the dansyl fluorophore to be a core-structure present in many fluorescent sensors and labels for the detection of both metal cations ${ }^{13-15}$ and anions, ${ }^{16,17}$ as well as in larger supramolecular structures such as dendrimers. ${ }^{18,19}$<smiles>[R]OS(=O)c1cccc2c(N(C)C)cccc12</smiles>

Figure 1. Molecular structure of dansyl fluorophore: $\mathrm{R}=\mathrm{Cl}$ (dansyl chloride) or $\mathrm{R}=\mathrm{NHCH}_{2} \mathrm{COOH}$ (dansylglycine).

The present paper describes the preparation of fluorescent films of a dansyl fluorophore immobilized on a polymer substrate. Due to its good film forming property and ease to be modified, ${ }^{20,21}$ chitosan is as an ideal substrate for preparation of functional films. Chitosan (Figure 2) is a biopolymer produced by partial deacetylation of chitin, derived from crustacean shells and is a member of the family of linear copolymers of 2-acetamido-2-deoxy- $\beta$-D-glucopyranose and 2 -amino-2-deoxy- $\beta$-D-glucopyranose. ${ }^{21-23}$ Chitosan and its derivatives are currently being studied for potential uses in such diverse fields as drug and gene delivery ${ }^{24,25}$ enzyme immobilization, ${ }^{26}$ polymer batteries, ${ }^{27}$ antimicrobial effect ${ }^{28}$ and metal ion removal from aqueous solutions. ${ }^{29}$

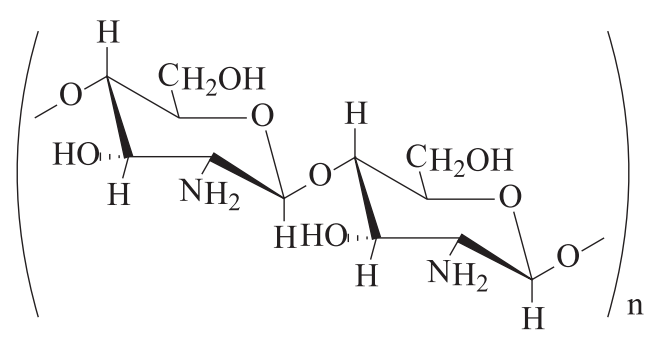

Figure 2. Molecular structure of chitosan.

Fluorescent chitosans can be obtained by the attachment of fluorescent groups to a polymer backbone ${ }^{30,31}$ or by the incorporation of several organic or inorganic materials, including transition metal ions, into the chitosan matrix. ${ }^{32-34}$ Numerous works have been recently published about the synthesis and characterizations of fluorescent chitosans based on fluorescent dyes. The interest for these materials is justified by the applications as luminescent probes to study the structure of polymeric matrices or to understanding the behavior of biological macromolecules and also as sensors in a great range of fields. ${ }^{23,31,35,36}$

In this work, chitosan was selected as a substrate and dansyl derivatives as fluorophore element to design and prepare a new kind of fluorescent films, which can be applied as an emitting layer in organic electroluminescent devices, ${ }^{37}$ since the photophysical properties related to intra-molecular charge transfer are useful for electroluminescence application. These films were prepared by two different methods: (i) chemical immobilization of dansyl chloride in a chitosan matrix coated onto an indium tin oxide (ITO) surface or (ii) electrodeposition of dansylglycine films on the ITO surface. The morphological, photochemical and electrochemical parameters of these films were determined and compared aiming purpose the appropriate deposition method according to the projected application for the functionalized film.

\section{Experimental}

\section{Materials and instruments}

Chitosan (Acros; MW 100,000-300,000), dansyl chloride (Sigma-Aldrich), dansylglycine (Sigma-Aldrich) and $\mathrm{LiClO}_{4}$ (Vetec) were used as supplied without further purification. $\mathrm{CH}_{3} \mathrm{CN}\left(\mathrm{H}_{2} \mathrm{O}<0.001 \%\right.$, Sigma-Aldrich $)$ was distilled over $\mathrm{P}_{2} \mathrm{O}_{5}$ prior to use. ITO electrodes $\left(1.0 \mathrm{~cm}^{2}\right.$, $R_{\mathrm{s}} \leq 10 \Omega \mathrm{cm}^{2}$; Delta Technologies) were employed as substrate for the chemical and electrochemical deposition of fluorescent films.

Electrochemical depositions and characterizations were performed in an Autolab PGSTAT30 galvanostat/ 
potentiostat. A platinum plate $\left(1.0 \mathrm{~cm}^{2}\right)$ was used as the counter electrode and a non-aqueous $\mathrm{Ag} / \mathrm{Ag}^{+}\left(\mathrm{CH}_{3} \mathrm{CN}\right)$ electrode $(+0.298 \mathrm{~V} v s$. normal hydrogen electrode), isolated from the working solution by a $\mathrm{Vycor}^{\circledR}$ frit, was used as reference.

Fluorescence spectra were measured at dry state (room temperature) using an ISS K2 Multifrequency Phase Fluorometer equipped with a $300 \mathrm{~W}$ xenon lamp and holographic grating (excitation), and a $25 \mathrm{~cm}$ monochromator $(0.1 \mathrm{~mm}$ resolution) and photomultiplier (emission). The excitation and emission monochromators were operated at slit widths of $0.5 \mathrm{~mm}$, both monochromators having 1200 grooves $\mathrm{mm}^{-1}$. The excitation spectra were obtained with a linear light beam whilst emission spectra were obtained at an angle of $34^{\circ}$ between the light beams.

Atomic force microscopy (AFM) images were acquired using a Shimadzu SPM-9500J3 microscope with a scanner of $125 \mu \mathrm{m}$ on the $\mathrm{x}-\mathrm{y}$ plane and $8 \mu \mathrm{m}$ along the $\mathrm{z}$ axis. The instrument was operated in the contact mode and was controlled by SPM Manager software (version 2.11). The cantilevers were needles of $\mathrm{Si}_{3} \mathrm{~N}_{4}(200 \mu$ m length; Olympus) with a resonance frequency of $24 \mathrm{kHz}$ and a spring constant of $0.15 \mathrm{~N} \mathrm{~m}^{-1}$.

\section{Preparation of dansyl chloride-chitosan films}

An aliquot $(100 \mu \mathrm{L})$ of a $1 \%(\mathrm{~m} / \mathrm{v})$ chitosan solution (prepared by dissolving $0.05 \mathrm{~g}$ of chitosan in $5.0 \mathrm{~mL}$ of $0.25 \mathrm{~mol} \mathrm{~L}^{-1}$ acetic acid) was distributed homogenously over the surface of an ITO electrode $\left(1.0 \mathrm{~cm}^{2}\right)$ treated with the RCA protocol. ${ }^{38,39}$ The coated plate was carefully transferred to a covered container, allowed to dry for $48 \mathrm{~h}$ at room temperature, and then immersed in a solution of dansyl chloride $(0.012 \mathrm{~g})$ in dry $\mathrm{CH}_{3} \mathrm{CN}(15.0 \mathrm{~mL})$ for $48 \mathrm{~h}$ at room temperature. After reaction, the electrode was rinsed several times with dry $\mathrm{CH}_{3} \mathrm{CN}$ and dried at room temperature for $24 \mathrm{~h}$.

\section{Electrodeposition of dansylglycine films}

Films were electrodeposited on ITO electrodes $\left(1.0 \mathrm{~cm}^{2}\right)$ from a solution containing $0.002 \mathrm{~mol} \mathrm{~L}^{-1}$ of dansylglycine and $0.1 \mathrm{~mol} \mathrm{~L}^{-1} \mathrm{LiClO}_{4}$ (as supporting electrolyte) in freshly distilled $\mathrm{CH}_{3} \mathrm{CN}$. Potentiodynamic method was employed in which the potential varied from $0.0 \mathrm{~V}$ to $-1.8 \mathrm{~V} v s . \mathrm{Ag} / \mathrm{Ag}^{+}$ at a scan rate $(\mathrm{v})$ of $0.020 \mathrm{~V} \mathrm{~s}^{-1}$, and the number of voltammetric cycles was varied between 2 and 5 in order to optimize the deposition conditions. Deposited films were washed several times with $\mathrm{CH}_{3} \mathrm{CN}$ to remove unreacted dansylglycine and excess of supporting electrolyte.
Morphological and electrochemical characterization of the films

The surfaces of the chitosan, dansyl chloride-chitosan and electrodeposited dansylglycine films were scanned by AFM over areas measuring $10 \times 10 \mu \mathrm{m}$ at a maximum scan rate of $1.0 \mathrm{~Hz}$ and at resolutions of above $512 \times 512$ lines. The mapped surface images were processed by flattening to best fit the inclination, contrast and brightness.

Cyclic voltammograms of the dansyl derivatives films were registered in a potential range of -0.6 to $0.1 \mathrm{~V}$, $v=0.02 \mathrm{~V} \mathrm{~s}^{-1}$, using a $\mathrm{LiClO}_{4} / \mathrm{CH}_{3} \mathrm{CN} 0.1 \mathrm{~mol} \mathrm{~L}^{-1}$ solution as electrolyte.

\section{Results and Discussion}

Electrochemical characterization of dansyl derivatives and electrodeposition of dansylglycine films

Cyclic voltammograms showing the electrochemical behavior of the dansyl chloride and dansylglycine derivatives in $\mathrm{LiClO}_{4} / \mathrm{CH}_{3} \mathrm{CN}$ in the anodic and cathodic regions are displayed in Figure 3 and Figure 4, respectively. According to the functional groups present in the molecular structure of dansyl chloride and dansylglycine, the following electrochemical reactions can be possible in aprotic media: $(i)$ the anodic oxidation of the tertiary amine at the range of 0.6 to $1.5 \mathrm{~V}$, depending on the substituent, ${ }^{40-42}$ (ii) the electroreduction of the carboxylic acid (just for the dansylglycine) at $c a$. $-1.5 \mathrm{~V}$, giving carboxylate anions that can rearrange and form a series of different products ${ }^{42}$ and (iii) at more cathodic potential (above $-2.0 \mathrm{~V}$ ), the sulfonyl chloride $\mathrm{S}-\mathrm{Cl}$ or the sulfonamide $\mathrm{S}-\mathrm{N}$ bond cleavage. ${ }^{43,44}$

In the anodic region, the cyclic voltammograms revealed an irreversible peak at $0.706 \mathrm{~V}$ for the dansyl

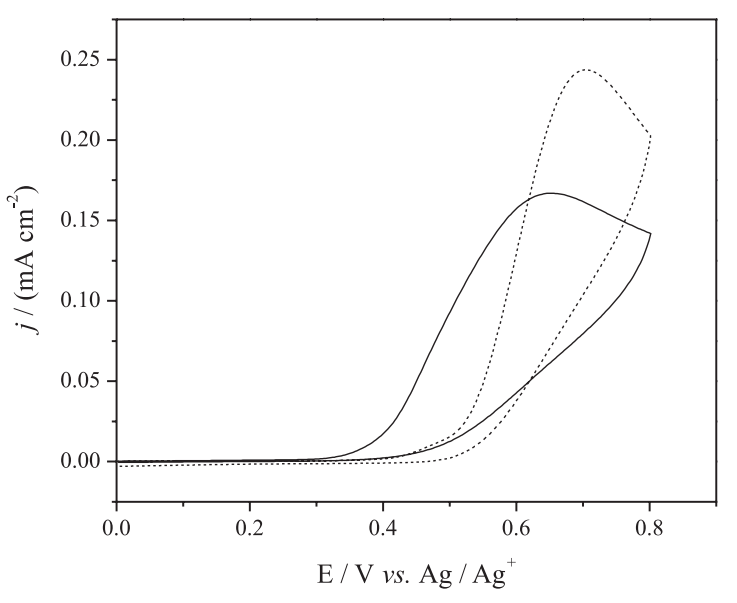

Figure 3. Cyclic voltammograms of dansylchloride (---) and dansylglycine (-) in $0.1 \mathrm{~mol} \mathrm{~L}^{-1} \mathrm{LiClO}_{4} / \mathrm{CH}_{3} \mathrm{CN}$ with $v=0.020 \mathrm{~V} \mathrm{~s}^{-1}$. 


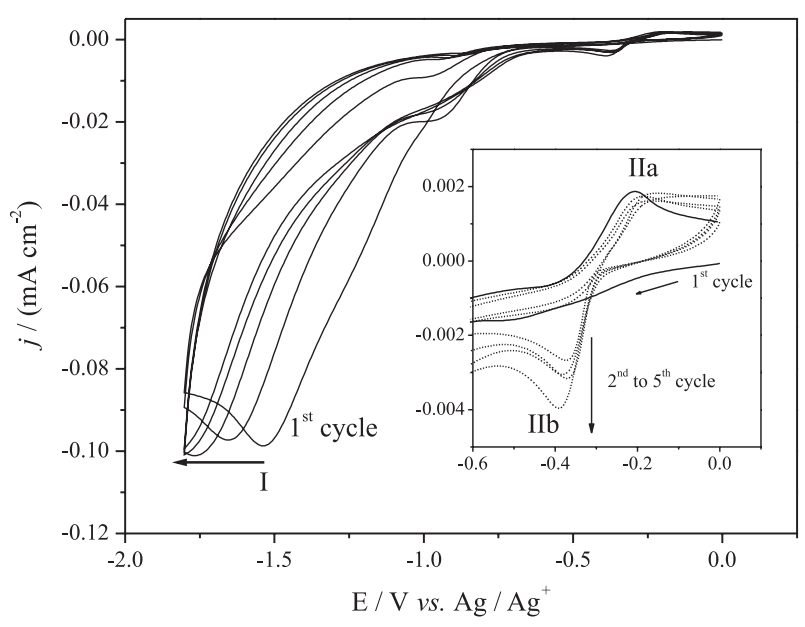

Figure 4. Cyclic voltammograms registered during the electrodeposition of the dansylglycine films on ITO in $0.1 \mathrm{~mol} \mathrm{~L}^{-1} \mathrm{LiClO}_{4} / \mathrm{CH}_{3} \mathrm{CN}$ with $v=0.020 \mathrm{~V} \mathrm{~s}^{-1}$.

chloride and at $0.654 \mathrm{~V}$ vs. $\mathrm{Ag} / \mathrm{Ag}^{+}$for the dansylglycine (Figure 3). These peaks were attributed to the tertiary amine oxidation of both derivatives, suggesting a fast following coupled chemical reaction and/or an irreversible charge transfer reaction, but with no significant changes observed at the electrode surface.

Figure 4 displays the cyclic voltammograms acquired during the cycling in the potential range of 0.0 to $-1.8 \mathrm{~V}$. The first voltammetric scan of the dansylglycine in $\mathrm{LiClO}_{4} / \mathrm{CH}_{3} \mathrm{CN}$ showed and irreversible peak (I) at $-1.537 \mathrm{~V}$, that can be assigned to the carboxylate anion or anion radical generation with expected consecutive chemical steps, resulting in self-protonation ${ }^{45}$ or side reactions giving dimers or oligomers onto the ITO surface..$^{42}$ The reverse scan showed another peak (IIa) at $-0.209 \mathrm{~V}$, related to the oxidation of the product generated after the first reduction step, once peak IIa was not present when the cathodic scan range was limited to $-1.0 \mathrm{~V}$. Furthermore the successive cycling evidenced the displacement of the peak I to more cathodic potentials $(c a .-1.8 \mathrm{~V})$ and also the appearance of a new peak (IIb) at $-0.374 \mathrm{~V}$, identified as the correspondent reduction of IIa.

Attempts to deposit dansyl chloride by electrochemical methods were performed using the same experimental conditions used to deposit dansylglycine, however, the film formation on the ITO surface was not observed. A possible explanation for this behavior is that deposition of dansyl derivatives is conditioned by the reduction of the carboxylic acid group present in the dansylglycine.

Concerning the discussions about the electrochemical behaviour of the dansyl derivatives, there are few works published in the literature. In their work, Fontanesi et al. ${ }^{46}$ investigated the reduction of tosylglycine and dansylglycine in several solvents by polarographic measurements using $\mathrm{Hg}$ electrode and proposed the formation of carboxylate anions in aprotic media. Another paper, published by Illos et al. ${ }^{47}$ describes the synthesis of a new dansyl derivative bearing a carbazoloquinone moiety for apply this system as an electrochemical fluorescent switch, but these authors focused the data interpretation just for the electrochemical response of the quinone-hydroquinone redox pair.

\section{Electrochemical characterization of the dansylglycine and} dansyl chloride-chitosan films

Cyclic voltammograms of the two immobilized dansyl films, recorded in $\mathrm{LiClO}_{4} / \mathrm{CH}_{3} \mathrm{CN}$ as supporting electrolyte, are presented in Figure 5. The electrochemically deposited dansylglycine film (full line) exhibited a shoulder at $-0.228 \mathrm{~V}$, not visualized during the electrodeposition process, and a redox pair with cathodic peak potential $\left(E_{\mathrm{pc}}\right)$ at $-0.389 \mathrm{~V}$ and anodic peak potential $\left(E_{\mathrm{pa}}\right)$ at $-0.092 \mathrm{~V} v$ s. $\mathrm{Ag} / \mathrm{Ag}^{+}$. This is a classical behavior of an electroactive film, with cathodic integrated charge of ca. $24 \mathrm{mC} \mathrm{cm}^{-2}$. The chemically formed dansyl chloridechitosan film showed no electrochemical response over the potential range investigated (dash line), justified by the ITO electrode passivation by the chitosan film.

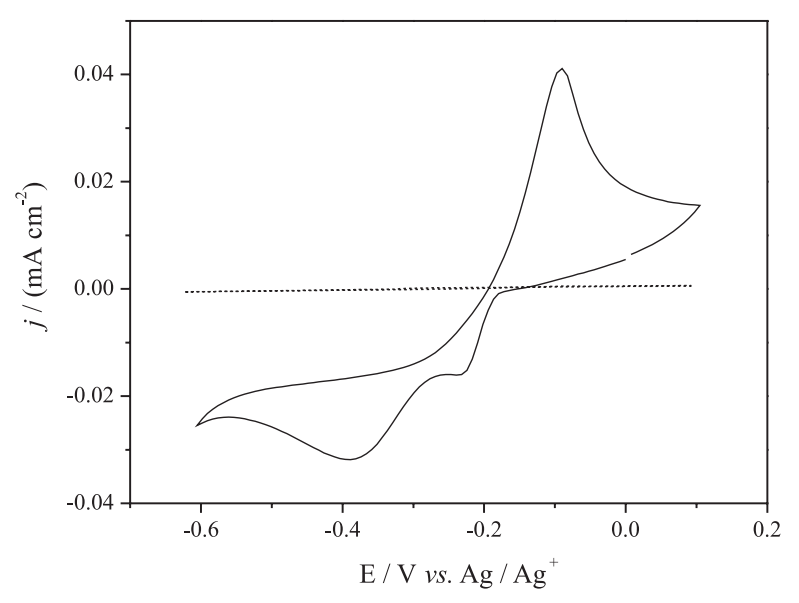

Figure 5. Cyclic voltammograms of dansylchloride-chitosan (---) and dansylglycine (prepared with 5 voltammetric cycles) (-) films deposited on ITO electrodes in $0.1 \mathrm{~mol} \mathrm{~L}^{-1} \mathrm{LiClO}_{4} / \mathrm{CH}_{3} \mathrm{CN}$ with $\mathrm{v}=0.020 \mathrm{~V} \mathrm{~s}^{-1}$.

\section{Morphological characterization}

Representative two- and three-dimensional AFM images of chitosan and dansyl chloride-chitosan films are portrayed in Figures 6A and 6B, respectively. The chitosan film presented a plain homogeneous surface exhibiting very low dispersion in the roughness profile, whilst the dansyl chloride-chitosan film displayed a non-homogeneous 


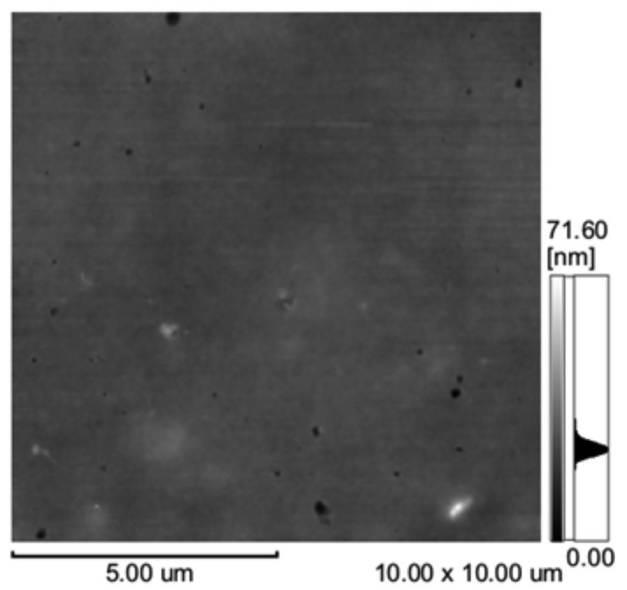

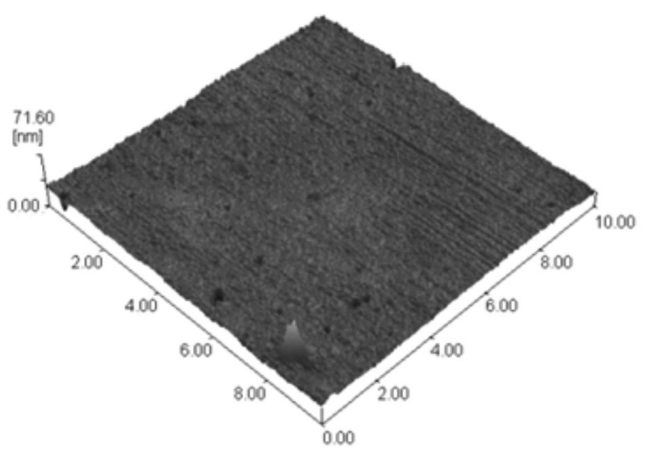

$10.00 \times 10.00[\mathrm{um}] \quad \mathrm{Z} 0.00-71.60[\mathrm{~nm}]$

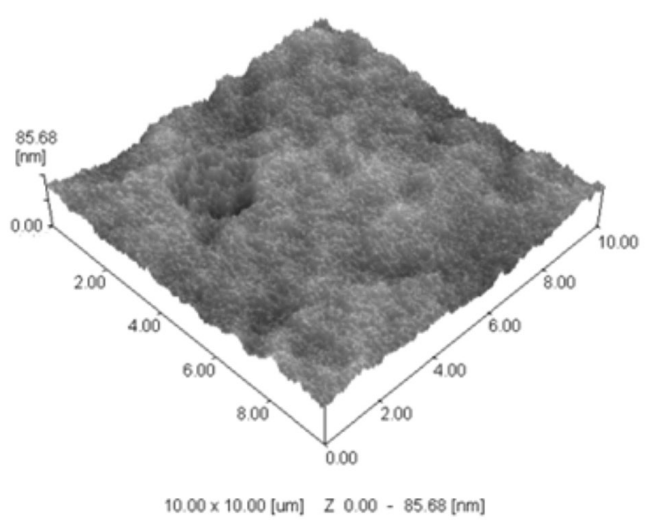

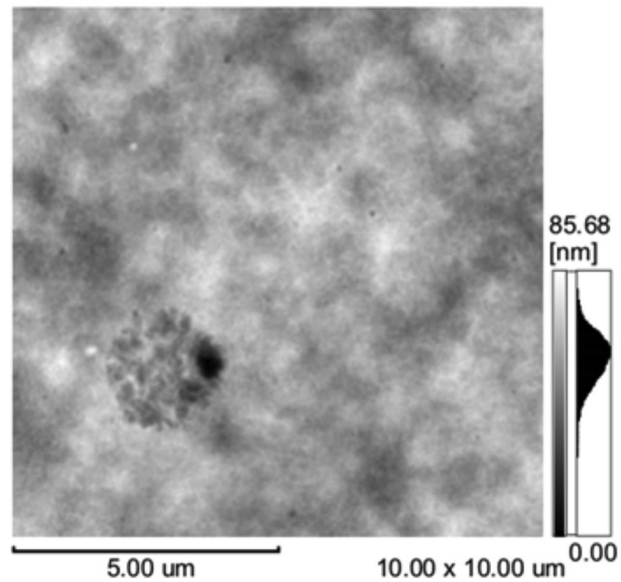

Figure 6. Two- and three-dimensional AFM images of films of (A) chitosan and (B) dansychloride-chitosan deposited on ITO. The roughness profile and height maximum (nm) for each film are presented alongside the corresponding 2D-image.

surface with some roughness. Evidently, expressive modifications to the film surface occurred during the reaction between the dansyl chloride and the amino groups of the chitosan, giving a fluorescent film deposited onto the ITO surface, due to the sulfonamide formation.

AFM images of dansylglycine films deposited electrochemically on ITO electrodes with 3 and 5 voltammetric cycles are depicted, respectively, in Figures 7A and 7B. These films presented well-organized rice-grain type structures exhibiting high dispersion in the roughness profile. In films electrodeposited with 3 voltammetric cycles, the grains grew to $c a .400-500 \mathrm{~nm}$ in length and $100 \mathrm{~nm}$ in diameter, and most of them were orientated in the co-planar direction (Figure 7A). In contrast, the grains of the films produced with 5 voltammetric cycles showed a tendency to grow in the vertical direction, forming polyp-like structures with thicknesses of $c a$. 200-300 nm and heights of $600-700 \mathrm{~nm}$ (Figure 7B). It is thus clearly possible to control both thickness and morphology of electrodeposited dansylglycine films by adjusting the number of voltammetric cycles, which is related to the deposition charge $\left(Q_{\text {dep }}\right){ }^{48}$

The arithmetic mean roughness $\left(R_{\mathrm{a}}\right)$, the square average roughness $\left(R_{\mathrm{ms}}\right)$ and the relative surface area of the chitosan, dansylchloride-chitosan and electrodeposited dansylglycine films, are presented in Table 1. These data indicate that the morphological parameters vary markedly as a function of the deposition method used to obtain the fluorescent film, as can be seen in the fluorescent emissions when exposed to ultraviolet light irradiation $(366 \mathrm{~nm})$, of the dansyl chloridechitosan film and of the electrodeposited dansylglycine film (dry condition). It may be observed that the electrodeposited dansylglycine film, which exhibited higher roughness parameters and a larger relative surface area, exhibited a very much stronger fluorescence emission under ultraviolet light.

\section{Steady state fluorescence}

The steady-state excitation and emission fluorescence spectra of the dansyl chloride-chitosan and electrodeposited 


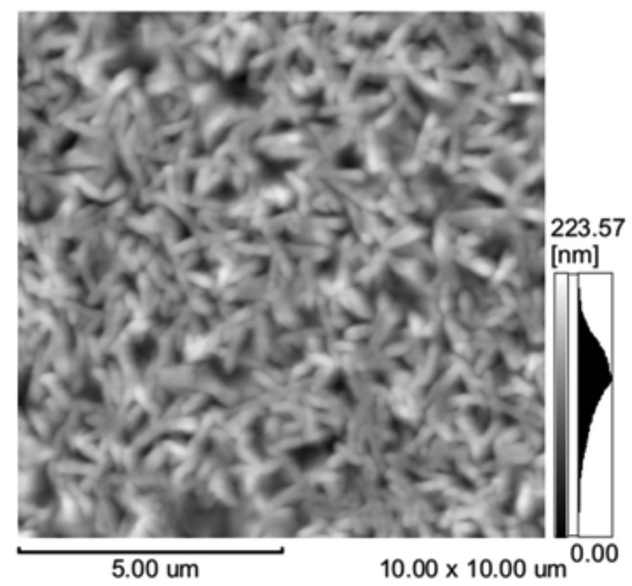

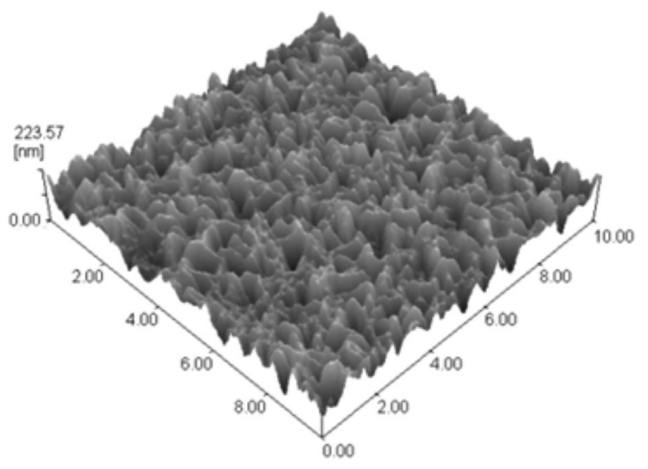

$10.00 \times 10.00[\mathrm{um}] \quad \mathrm{Z} 0.00-223.57[\mathrm{~nm}]$

\section{A}
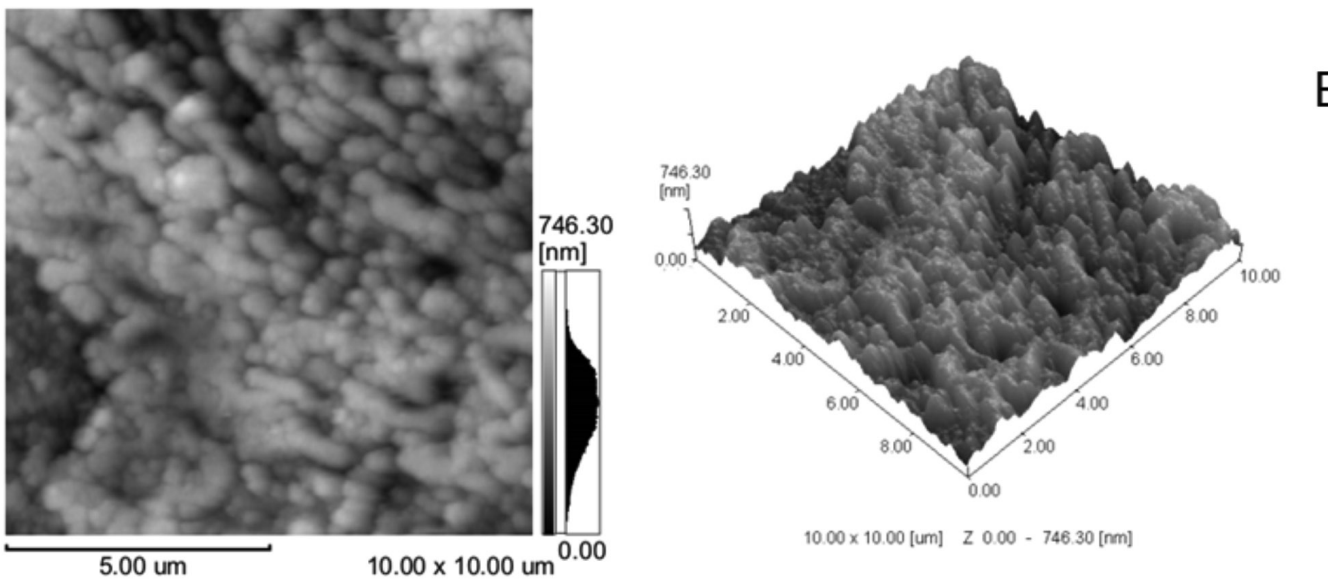

B

Figure 7. Two- and three-dimensional AFM images of films of (A) dansylglycine (electrodeposited with 3 voltammetric cycles) and (B) dansylglycine (electrodeposited with 5 voltammetric cycles) on ITO. The roughness profile and height maximum (nm) for each film are presented alongside the corresponding 2D-image.

Table 1. Values of arithmetic mean roughness $\left(R_{\mathrm{a}}\right)$, square average roughness $\left(R_{\mathrm{ms}}\right)$ and relative surface area of a chitosan film, a dansylchloride-chitosan film and electrodeposited dansylglycine films

\begin{tabular}{lccc}
\hline Film & $R_{\mathrm{a}} / \mathrm{nm}$ & $R_{\mathrm{ms}} / \mathrm{nm}$ & Relative surface area \\
\hline Chitosan & 1.506 & 2.172 & 1.001 \\
Dansylchloride-chitosan film & 6.317 & 8.036 & 1.005 \\
Electrodeposited dansylglycine with 3 voltammetric cycles & 24.11 & 30.38 & 1.063 \\
Electrodeposited dansylglycine with 5 voltammetric cycles & 86.60 & 105.5 & 1.207 \\
\hline
\end{tabular}

dansylglycine functional films at dry state are shown in Figures $8 \mathrm{~A}$ and $8 \mathrm{~B}$, respectively.

The emission spectra of the electrodeposited dansylglycine film consist of two bands, of which one situates at $435 \mathrm{~nm}$, named as band $\mathrm{B}$, and the other at $450 \mathrm{~nm}$, named as band A. According to the model proposed by Ding et al., ${ }^{6}$ dansyl in the immobilized state exists mainly in lonely monomer state. When the fluorophore is excited, three excited states would be formed and decay differently. The lifetime of non-CT excited state is shorter because it is less stable than the others. Emission from this excited state occurs at shorter wavelengths, and it is the so-called band $\mathrm{B}$. The lifetime of TICT excited state is longer than that of non-CT, then emission of it occurs at longer wavelength, and it is the so-called band A. In this way, the dual fluorescence may be attributed to the emission from the locally excited or the non-CT state (emission at $435 \mathrm{~nm}$ ) and that from the TICT state (emission at longer wavelength), respectively. Based on this result, we drew a conclusion that there exists a TICT state for dansylglycine electrochemically immobilized on the ITO surface. 


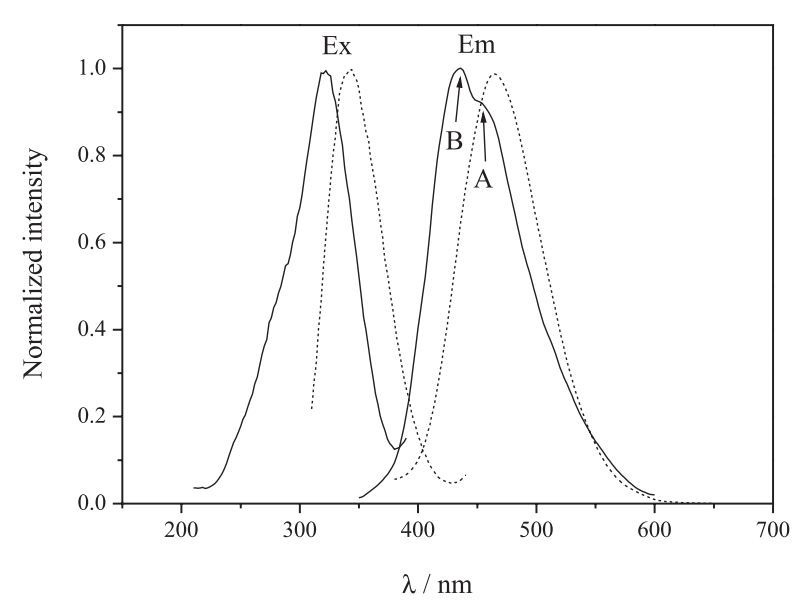

Figure 8. Fluorescence excitation scan spectra (A) and fluorescence emission scan spectra (B) of films of dansylchloride-chitosan (---) and dansylglycine (prepared with 5 voltammetric cycles) (-) deposited on ITO.

The dansyl chloride-chitosan (Figure 8, dash line) film showed only one symmetric emission band with slight differences in the position of the maximum fluorescence intensity (red shift) with respect to the electrodeposited dansylglycine film (Figure 8, full line). This behavior can be justified in terms of the solid state stabilization of dansyl groups by chitosan, once this polymer has a multifunctional molecular structure containing large numbers of amine groups, which is easy to react with dansyl chloride. After the reaction, the sulfonyl chloride group in the fluorophore must be converted into sulfonamide, which is a strong electron-withdrawing group and favors formation of TICT state when the fluorophore is excited. ${ }^{49}$ However, as it was observed only one emission band in the dansyl chloridechitosan film fluorescence spectrum, TICT phenomenon was not observed in this case. Probably, the second band, characteristic of the TICT, was quenched due to the presence of water residue in chitosan film.

Furthermore, the emission bands are well separated from the excitation ones, showing a Stokes shift of 115 and $120 \mathrm{~nm}$ for electrodeposited dansylglycine and dansyl chloride-chitosan films, respectively. The magnitude of the Stokes shift of the film depends on the nature of the environment, by which the film is surrounded. ${ }^{50}$

\section{Conclusions}

Films employing the dansyl group as fluorophore may be readily prepared using chemical or electrochemical methods and exhibit two fundamental characteristics, namely, electrochemical response and visible light fluorescence. It has been shown that, together with fluorimetric and electrochemical characterization, determination of the morphological parameters of a film provides a useful tool by which to define the appropriate deposition method according to the projected application for the material, i.e. as an emitting layer in organic electroluminescent devices or as a sensor.

\section{Acknowledgements}

The authors wish to thank the Brazilian granting authorities Conselho Nacional de Desenvolvimento Científico e Tecnológico (CNPq), Fundação de Amparo à Pesquisa do Estado de Alagoas (FAPEAL), Financiadora de Estudos e Projetos (FINEP) and Coordenação de Aperfeiçoamento de Pessoal de Nível Superior (CAPES) for financial support and for fellowships to A. J. C. S. (CAPES). The authors are also grateful to Instituto Nacional de Ciência e Tecnologia (INCT-INAMI) and to Braskem Co. (Brazil) for partnership in technological development and to Gleidson P.O. Silva for technical contributions.

\section{References}

1. Ding, L.; Kang, J.; Lu, F.; Gao, L.; Yin, X.; Fang, Y; Thin Solid Films 2007, 515, 3112.

2. Kakkar, A. K.; Chem. Rev. 2002, 102, 3579.

3. Roberts, C.; Chen, C. S.; Mrksich, M.; Martichonok, V., Ingber, D. E.; Whitesides, G. M.; J. Am. Chem. Soc. 1998, 120, 6548.

4. Atre, S. V.; Liedberg, B.; Allara, D. L.; Langmuir 1995, 11, 3882.

5. Zhang, C.; Luo, N.; Hirt, D. E.; Polymer 2005, 46, 9257.

6. Ding, L.; Fang, Y.; Jiang, L.; Gao, L.; Yin X.; Thin Solid Films 2005, 478, 318.

7. Li, D. Q.; Swanson, B. I.; Robinson, J. M.; Hoffbauer, M. A.; J. Am. Chem. Soc. 1993, 115, 6975.

8. Zhang, L.; Zheng, X.; Anal. Chim. Acta 2006, 570, 207.

9. Jin, Y.; Kim, J. Y.; Park, S. H.; Kim, J.; Lee, S.; Lee, K.; Suh, H.; Polymer 2005, 46, 12158.

10. Fujiwara, Y.; Amao, Y.; Sens. Actuators, B 2002, 85, 175.

11. Hayashi, Y.; Kawada, Y.; Ichimura, K.; Langmuir 1995, 11, 2077.

12. Parola, A. J.; Lima, J. C.; Pina, F.; Pina, J.; De Melo, J. S.; Soriano, C.; García-España, E.; Aucejo, R.; Alarcón, J.; Inorg. Chim. Acta 2007, 360, 1200.

13. Metivier, R.; Leray, I.; Lebeau, B.; Valeur, B.; J. Mater. Chem. 2005, 15, 2965.

14. Prodi, L.; Montalti, M.; Zaccheroni, N.; Dallavalle, F.; Folessani, G.; Lanfranchi, M.; Corradini, R.; Pagliari, S.; Marchelli, R.; Helv. Chim. Acta 2001, 84, 690.

15. Ding, L.; Cui, X.; Han, Y.; Lu, F.; Fang, Y.; J. Photochem. Photobiol., A 2007, 186, 143.

16. Chen, C.-F.; Chen, Q.-Y.; Tetrahedron Lett. 2004, 45, 3957. 
17. Liu, S.-Y.; He, Y.-B.; Qing, G.-Y.; Xu, K.-X.; Qin, H.-J.; Tetrahedron: Asymmetry 2005, 16, 1527.

18. Ceroni, P.; Vicinelli, V.; Maestri, M.; Balzani, V.; Lee, S.K.; van Heyst, J.; Gorka, M.; Vogtle, F.; J. Organomet. Chem. 2004, $689,4375$.

19. Mohanty, S. K.; Baskaran, S.; Mishra, A.K.; Eur. Polym. J. 2006, 42, 1893.

20. Jiang, Z.; Yu, Y.; Wu, H.; J. Membr. Sci. 2006, 280, 876.

21. Notin, L.; Viton, C.; David, L.; Alcouffe, P.; Rochas, C.; Domard, A.; Acta Biomater. 2006, 2, 387.

22. Thanpitcha, T.; Sirivat, A.; Jamieson, A. M.; Rujiravanit, R.; Carbohydr. Polym. 2006, 64, 560.

23. Tommeraas, K.; Strand, S. P.; Tian, W.; Kenne, L.; Varuma, K. M.; Carbohydr. Res. 2001, 336, 291.

24. Han, H. D.; Song, C. K.; Park, Y. S.; Noh, K. H.; Kim, J. H.; Hwang, T.; Kim, T. W.; Shin, B. C.; Int. J. Pharm. 2008, 350, 27.

25. Weecharangsan, W.; Opanasopit, P.; Ngawhirunpat, T.; Apirakaramwong, A.; Rojanarata, T.; Ruktanonchai, U.; Lee, R. J.; Int. J. Pharm. 2008, 348, 161.

26. Li, W.; Yuan, R.; Chai, Y.; Zhou, L.; Chen, S.; Li, N.; J. Biochem. Biophys. Methods 2008, 70, 830.

27. Ng, L. S.; Mohamad, A. A.; J. Power Sources 2006, 163, 382. 28. Rhoades, J.; Roller, S.; Appl. Environ. Microbiol. 2000, 66, 80.

29. Paulino, A. T.; Santos, L. B.; Nozaki, J.; React. Func. Polym. 2008, 68, 634.

30. Fernandes, S. C. M.; Freire, C. S. R.; Silvestre, A. J. D.; Pascoal Neto, C.; Gandini, A.; Desbrières, J.; Blanc, S.; Ferreira, R. A. S.; Carlos, L. D.; Carbohydr. Polym. 2009, 78, 760.

31. Munro, N. H.; Hanton, L. R.; Robinson, B. H.; Simpson, J.; React. Func. Polym. 2008, 68, 671.

32. Lee, Y.-H.; Chang J.-J.; Lai, W.-F.; Yang, M.-C.; Chien C.-T.; Colloids Surf., B 2011, 86, 409.

33. Yan, E.; Wang, C.; Wang, S.; Sun, L.; Wang, Y.; Fan, L.; Zhang, D.; Mater. Sci. Eng., B 2011, 176, 458.

34. Xia, H.; He, G.; Peng, J.; Li, W.; Fang, Y.; Appl. Surf. Sci. 2010 , 256,7270 .
35. Mi, F.-L.; Shyu, S.-S.; Peng, C.-K.; J. Polym. Sci., Part A: Polym. Chem. 2005, 43, 1985.

36. Zhang, S.-J.; Fang, Y.; Hu, D.-D.; Gao, G.-L.; Chin. J. Chem. 2003, 21, 249.

37. Kalinowski, J.; Optical Materials 2008, 30, 792.

38. Kim, J. S.; Granstrom, M.; Friend, R. H.; Johansson, N.; Salaneck, W. R.; Daik, R.; Feast, W. J.; Cacialli, F.; J. Appl. Phys. 1998, 84, 6859.

39. Armstrong, N. R.; Cartera, C.; Donley, C.; Simmonds, A.; Lee, P.; Brumbash, M.; Kippelen, B.; Domercq, B.; Yoo, S.; Thin Solid Films 2003, 445, 342.

40. Chiu, K. Y.; Su, T. X.; Li, J. H.; Lin, T.-H.; Liou, G.-S.; Cheng, S.-H.; J. Electroanal. Chem. 2005, 575, 95.

41. Cruickshank, A. M.; Tan, E. S. Q.; Brooksby, P. A.; Downard, A. J.; Electrochem. Commun. 2007, 9, 1456.

42. Lund, H.; Hammerich, O.; Organic Electrochemistry, $4^{\text {th }}$ ed.; Marcel Dekker, Inc.: New York, 2001.

43. Angelo, A. C. D.; Jorge, S. M. A.; Stradiotto, N. R.; Eclét.Quím. 2005, 30, 57.

44. Dubey, S.; Fabre, B.; Marchand, G.; Pilard, J.-F.; Simonet, J.; J. Electroanal. Chem. 1999, 477, 121.

45. Azevedo, D. C.; Boodts, J. F. C.; Cavalcanti, J. C. M.; Santana, A. E. G.; dos Santos, A. F.; Bento, E. S.; Tonholo, J.; Goulart, M. O. F.; J. Electroanal. Chem. 1999, 466, 99.

46. Fontanesi, C.; Borsari, M.; Andreoli, R.; Benedetti, L.; Grandi, G.; Gavioli, G. B.; Electrochim. Acta 1989, 34, 759.

47. Illos, R. A.; Shamir, D.; Shimon, L. J. W.; Zilbermann, I.; Bittner, S.; Tetrahedron Lett. 2006, 47, 5543.

48. Ribeiro, A. S.; Nogueira, V. C.; Santos, P. F.; De Paoli, M.-A.; Electrochim. Acta 2004, 49, 2237.

49. Grabowski, Z. R.; Rotkiewicz, K.; Retting, W.; Chem. Rev. 2003, 103, 3899.

50. Olmos, D.; Lopez-Moron, R.; Gonzalez-Benito, J.; Compos. Sci. Technol. 2006, 66, 2758.

Submitted: February 11, 2011 Published online: July 12, 2011 